\title{
Knowledge Sharing for the Islamic Banking Sector in Malaysia
}

\author{
Abdusalam A. A. Abuazoum, Nurdiana Azizan, and Nursilah Ahmad
}

\begin{abstract}
This study investigates the causes of resistance or support by knowledge workers to the sharing of knowledge. Today, banks are starting to understand the relevance and importance of knowledge sharing. They are also beginning to appreciate knowledge as the most significant and valued asset that leads to organizational performance. Hence, promising motivational factors are expected to be helpful in emphasizing the need for employees to share not only crucial knowledge but also new knowledge to further ensure that the banking industry possesses the competitive edge they seek. This study investigates and thoroughly examines the intrinsic (trust, learning, behavior) and extrinsic (organization culture, reward system information technology) motivational factors that encourage widespread knowledge sharing among bank employees, especially in the dynamic and ever-growing Islamic banking sector in Malaysia. The research findings provide useful information and help deepen the understanding of banks about motivating their employees' tendencies to engage in knowledge sharing practices.
\end{abstract}

Index Terms-Knowledge sharing, islamic banking, islamic banks.

\section{INTRODUCTION}

Since the emergence of the well-known knowledge era that is radically changing the values in organizations [1], the long-term viability and prosperity of organizations have been viewed to be increasingly dependent on the organizations' ability to leverage the concealed worth of this crucially acquired intangible knowledge. As the continuous change in market expectations and the demands for new products introduced by knowledge-intensive firms had gradually replaced the commodities of the capital and labor-intensive firms in previous years [2]. Knowledge sharing (KS) is unquestionably an important component for all organizations, especially for banking institutions pursuing knowledge as an intangible and well sought-after asset. In distinguishing the competitive and rapidly changing environment, KS does play an important role because it enables not only intellectual reuse but also the renewal of knowledge that is possessed by bank employees. Therefore, [3] emphasizes that these organizations must continuously motivate their employees to share valuable information so that their intellectual capital

Manuscript received November 10, 2012; revised January 28, 2013.

Abdusalam A. A. Abuazoum is with the Faculty of Science and Technology, Universiti Sains Islam Malaysia (e-mail: mukm2012@yahoo.com).

Nurdiana Azizan is with the Computer Science Program at Faculty of Science and Technology, Universiti Sains Islam Malaysia (e-mail: nurdiana@usim.edu.my).

Nursilah Ahmad is with the Corporate Administration and Relations Program at Faculty of Economics and Muamalat, Universiti Sains Islam Malaysia (e-mail: nursilah@usim.edu.my). can be leveraged.

In recent years, numerous researchers and scholars have placed a great deal of emphasis on the need to create a KS culture in organizations and to implement business strategies that are more knowledge friendly. At the same time, organizations worldwide have been trying to undertake initiatives in introducing effective knowledge management (KM) by embedding KS practices in their daily work processes to achieve organizational performance [2]. For centuries, numerous banking services have grown to include financial services directed at both businesses and individuals at large, indirectly influencing economic practices, particularly in Malaysia's banking arena. Hence, implementing KM initiatives is considered by the banking industry as vitally important to spearheading Malaysia's economy. Consequently, banks pick up the initiative in setting up KM teams within their organizations [4]. With this in mind, banking institutions have realized that $\mathrm{KS}$ in $\mathrm{KM}$ should neither be deserted nor neglected in boosting their survival in this ever-challenging competitive environment. This study aims to examine KS strategies that help increase the tendencies of employees in Islamic banks in Malaysia to engage in KS practices.

\section{PROBLEM STATEMENT}

What differentiates Malaysia from other Islamic countries is the manner by which the Malaysian government has managed to implement a parallel system, wherein Islamic and conventional banks can function alongside each another, rather than full Islamisation [5]. The issue in our study includes insufficient personnel training [6]. Many Islamic banks recruit their employees from conventional banks, and these employees sometimes experience problems in understanding Shari'ah rulings. In conventional banks, which implement parallel system (Islamic banks) allows institutions to offer Islamic banking products and services using their existing infrastructure, including staff and branches [7]. This issue is to hire non-Muslim staff, and to hire staff that does not have information or knowledge about Shari'ah. This would create problem in the Islamic banking services to customer and as well as on the correct non-application of religious texts.

The sharing of Islamic information among employees is weak because of the lack of appropriate training. As a result of the lack of independence of conventional Islamic banks, independent Islamic banks have become industry leaders, particularly because their employees are ready to share Islamic information. This result therefore reflects the problem on the growth and development of Islamic banking in Islamic banks as well as on the correct non-application of 
religious texts. The problem addressed was that existing knowledge was not being effectively disseminated throughout the organization.

\section{SCOPE OF STUDY}

This paper aims to assess the level of KS among the staff and managers of a number of Islamic banks in Malaysia. A questionnaire and support this result by interview is used to evaluate the exchange of experiences and knowledge, whether from documents or from all elements of knowledge, and to identify the problems that hinder KS in Islamic banks. The result of the questionnaires is analyzed using the SPSS software.

\section{OBJECTIVE}

To evaluate the Islamic KS activities by using IT among the staff of Islamic banks in Malaysia.

\section{LITERATURE REVIEW}

In order to remain competitive, companies not only require preserving knowledge but also share knowledge between individuals and functional groups. Sharing of knowledge can be defined as the dissemination of information and knowledge throughout the organization [8]. Knowledge sharing plays an essential role in the organizational process because it helps an organization to transfer new ideas or solutions [9]. When employees are interacting among one another for idea generation, it promotes the sharing of knowledge among them. Knowledge sharing enables the flow of knowledge among and between individuals, groups and organizations, [10] and [11], Indicate knowledge sharing to make the knowledge available to participate [12], find the knowledge of the difficulty in participation of others in order to keep them in the head of a person, other than the ease with which we find in the data and information that has viability access to the files or documents and to provide others with ease, whether as persons or organizations.

Islamic banking has become a substantial and fastest growing industry during the last four decades. It has followed the Islamic transactions rules and principles (Sharia'h) to carry out their business, [13]-[15]. In accordance with Sharia'h principles, any payment or receipt of interest is strictly prohibited. Although, the Islamic bank also offered services which are similar to those offered by a conventional bank.

Conventional banks, which implement parallel system (Islamic banks). What differs Malaysia from other Islamic countries is how the Malaysian government has managed to implement a parallel system, where Islamic and conventional banking can function alongside one another, rather than full Islamisation and was the country's first step towards the development of a dual system, where Islamic banking could function parallel to the conventional system [7].

\section{A. Theoretical Framework of this Study Organizational Knowledge Capability.}

The core capabilities of knowledge organization are important in providing information and knowledge based services [16], [17], claims that KM initiatives will fail if the investments of organizational resources and capabilities are inappropriate. In other words, effective KM should contribute to organizational performance through the development of organizational knowledge capability [18], [19], empirical research reveal that an organizational capability to learn or acquire the needed knowledge from other organizations is a key resource for successful knowledge sharing. Thus, the enhancement of knowledge capabilities as the foundation of organizational development is beneficial for organizational effectiveness. Normally, organizational capabilities invest on process improvement, work effectiveness, learning, and supporting technology that facilitate knowledge [16] (see Fig. 1).

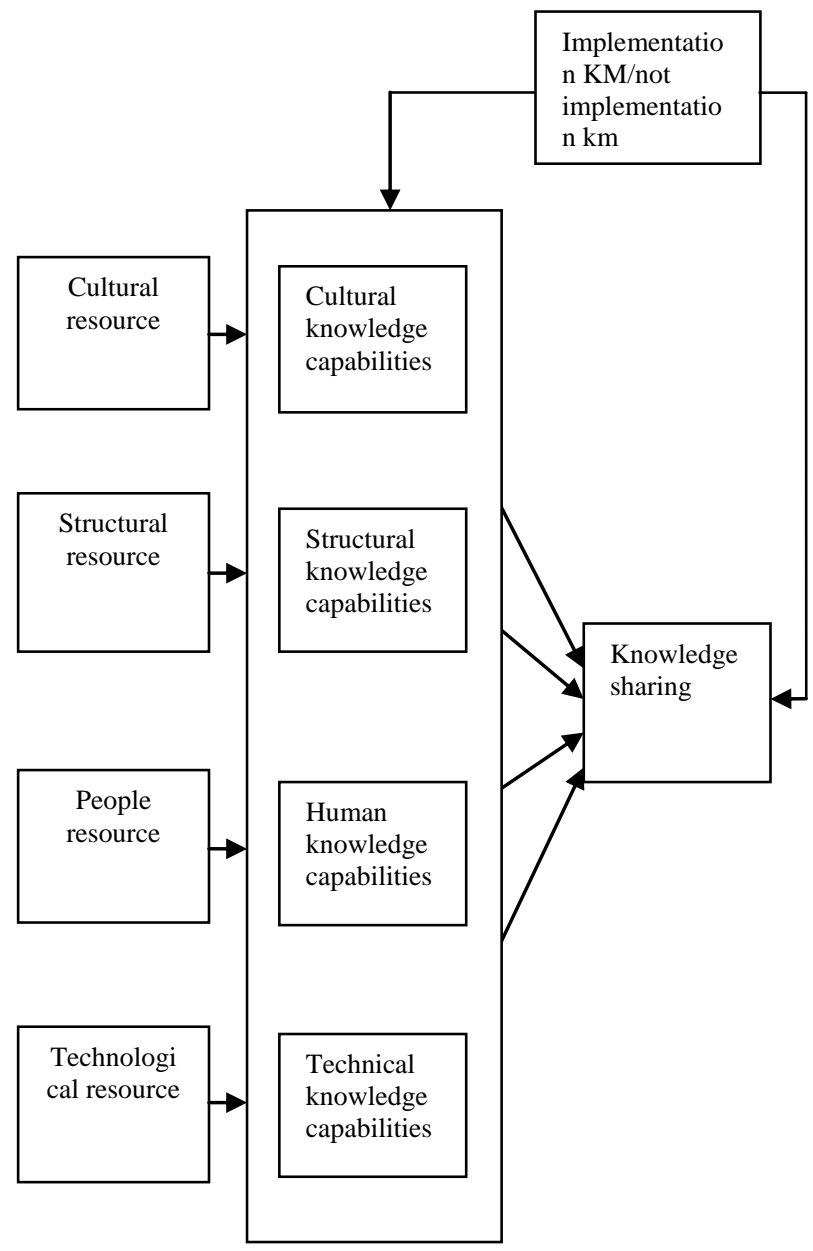

Fig. 1. A framework linking organizational knowledge capabilities to knowledge sharing Source [16].

\section{B. Background of Study}

The importance of research comes from the importance of the research variables in contemporary organizations and societies. This importance is also revealed through the ways by which organizations can be provided with information and communication technology to expand the possibilities of $\mathrm{KS}$, which could not have been achieved previously, and to provide real opportunities for $\mathrm{KS}$ to contribute to their strategic development. This study provides a significant influence and impact in determining the success of the sharing of warranted knowledge among Islamic bank employees in achieving desirable organizational competitiveness. The research findings provide useful information and help deepen the understanding of Islamic 
banks in motivating their employees' tendencies to engage in knowledge sharing practices.

\section{Research Methodology}

\section{A. Connect the Data}

Connecting the two data types, when the researcher realizes the need for further data collection for support of results, after analyzing the first set of data. The second phase of data collection, which follows from the results of the initial phase, is therefore, marginal and supportive, intended to explain the initial results. [20].

Design of research process: (see Fig. 2).

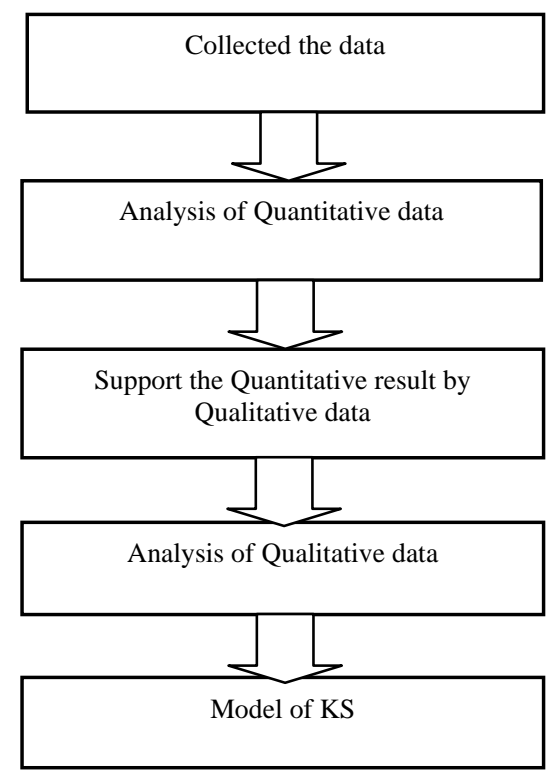

Fig. 2. Connect the data mixed method.

\section{B. Research Questions}

The research question for this paper is:

How to take advantage of information technology in the KS between the staff in Islamic banks in Malaysia?

\section{Expected Output}

A positive relationship exists between organizational support and KS in Islamic banks in Malaysia.

A positive relationship exists between $\mathrm{KS}$ and using IT in Islamic banks in Malaysia.

\section{Contribution}

Islamic banking is a growing sector in Malaysia and in many other countries. To improve the performance and to ensure the sustainable growth of Islamic banks, for $\mathrm{KS}$ among staff are one of the most important issues. The potential for $\mathrm{KS}$ in developing countries is reportedly higher than that in other parts of the world [21]. For the banking institutions to fully leverage their knowledge potential, they must first appreciate and look forward to the enablers that affect KS as a whole. This study is therefore expected to eventually facilitate and assist the banking sector in improving its recognition and understanding of the influencing factors that further induce KS in Islamic banks and in conventional banks with an Islamic banking window. The study is also anticipated to determine the status of
Islamic information sharing among the staff and the success of $\mathrm{KS}$ in the Islamic banks. This issue is to hire non-Muslim staff, and to hire the staffs that do not have information or knowledge about Shari'ah. This would create problem in the Islamic banking services to customer and as well as on the correct non-application of religious texts. For help the Islamic banks to overcome problem clashes and gain a deeper understanding of its staff needs and demands from during support knowledge sharing between them. The new staff will also be trained about KS between them, and will create more understand correct application of religious texts and to provide Islamic banking services correct.

\section{CONCLUSION}

In this paper, the KS problem and its effects on the KS process have been studied in the context of Islamic banks in Malaysia. For Islamic banking institutions to fully leverage their knowledge potential, they must first appreciate and look forward to the enablers and barriers that affect $\mathrm{KS}$ as a whole. This study is therefore expected to eventually facilitate and assist the Islamic banking sector in improving its recognition and understanding of KS among the staff in Islamic banks in Malaysia.

\section{ACKNOWLEDGMENT}

The Faculty of Science \& Technology, Universiti Sains Islam Malaysia has provided the grants to support this research. Mr. Abdusalam. A. A. Abuazoum would like to thank University Sains Islam Malaysia for funding this work. An extended thank is due to Dr. Nurdiana Azizan and Dr Nursilah Ahmad for their timely assistance and guidance.

\section{REFERENCES}

[1] Y. Carlisle, "Strategic thinking and knowledge management," Managing Knowledge, 2001.

[2] H. M. Ali and N. H. Ahmad, "Knowledge management In Malaysian Banks: A new paradigm," Journal of Knowledge Management Practice 7, 2006.

[3] F. Barachini, "Cultural and social issues for knowledge sharing," Journal of Knowledge Management, vol. 13, pp. 98-110, 2009.

[4] L. A. Leng and F. H. M. Nasaruddin, Application of knowledge management in Malaysian banks - A preliminary study, 2007, pp 396-401

[5] UKM. (April 2004). Overview of Islamic Banking in Malaysia. [Online]. Available: http://www.pkukmweb.ukm.my/ hairun/EX3613/Overview\%20of\%2 OIslamic\%20Banking\%20in\%20Malaysia.pd.

[6] K. Monzer, "Islamic Banks at the threshold of the third millennium. Special on issue Islamic Banking," Thunderbird International Business Review, vol. 41, pp. 445-460, 1999.

[7] K. F. Jamal, Comparative study Of Islamic Banking between Malaysia and Pakistan Universiti Utara Malaysia, 2006.

[8] C. W. Ling, M. S. Sandhu, and K. K. Jain, "Knowledge sharing in an american multinational company based in Malaysia," J. Workplace Learn, vol. 21, no. 2, pp. 125-142, 2009.

[9] Z. Islam, Z. A. Ahmad, and H. Mahtab, "The mediating effects of socialization on organizational contexts and knowledge sharing,".J. Knowl. Global, vol. 3, no. 1. pp. 31-48, 2010.

[10] W. B. Gee and Y. Kim, "Breaking the myths of rewards: An exploratory study of attitudes about knowledge sharing," Inform. Resour. Manage. J., vol. 15, no. 2, pp. 14-21, 2002.

[11] J. C. Huang and S. Newell, "Knowledge integration process and dynamics within the context of cross-functional projects," Int. J. Proj. Manage. vol. 21, pp. 167-176, 2003.

[12] K. C. Laudon and J. P Laudon, Management information systems-managing the digital firm, Prentice Hall, 2004. 
[13] C. M. Henry and R. Wilson, The politics of islamic finance, Edinburgh: Edinburgh University Press, 2004.

[14] A. Dusuki, W. Abdullah, and N. Irwani, "Why do Malaysian customers patronise Islamic Banks?" International Journal of Bank Marketing, vol. 25 , no. 3, pp. 142-160, 2007.

[15] Z. Iqbal and A. Mirakhor, An introduction to Islamic Finance: Theory and practice, Chichester: John Wiley and Sons Ltd., 2007.

[16] C. Yang and L. C. Chen, "Can organizational knowledge capabilities affect knowledge sharing behavior?" Journal of Information Science. vol. 33, pp. 95-109, 2007.

[17] K. M. Wiig, Knowledge Management, Texas: Schema Press, 1994.

[18] Y. Malhotra, Knowledge management and business model innovation, Idea Group Inc (IGI), 2001.

[19] J. N. Lee, "The impact of knowledge sharing, organizational capability and partnership quality on IS outsourcing success," Information and Management. vol. 38, no. 5, pp. 323-335, 2001

[20] J. W. Cresswell and P. Clark, Designing and conducting mixed methods research, Thousand Oaks: Sage, 2007.

[21] S. C. Voelpel and Z. Han, "Managing knowledge sharing in china: The case of siemens sharenet," Journal of Knowledge Management, vol. 9, no. 3, pp. 51-63, 2005.

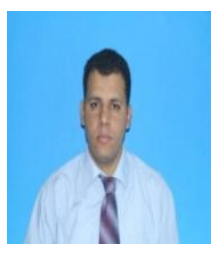

Abdusalam Abdulazez Abdulla Abuazoum obtained his B.Sc. physics University Sabha Libya, in the year 2004. He obtained his M.Sc. science ICT from University Utara Malaysia, in 2008. He has been awarded a full scholarship ministry of Higher Education \& scientific research of Libya to pursue his $\mathrm{PhD}$ degree in management information system, in computer science department, University Sains Islam

Malaysia. His Work Experiences: (2008-2011) as a lecturer at University Sabha Libya, and supervisor of communication in constructions Company in Libya.

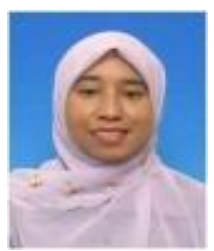

Nurdiana Azizan received her bachelor degree in Management Information Systems from Clarkson University, Potsdam New York USA, a master degree in Information Management from University Technology Mara, Shah Alam Malaysia and a PhD in Business Information Systems from RMIT University, Melboune Australia. Currently, she is a senior lecturer of Information Systems in the Faculty of Science and Technology at Universiti Sains Islam Malaysia. Her articles have appeared in Journal of e-Government Studies and Best Practices, and other refereed journals and conference proceedings. Her current research interests focus on knowledge management, electronic commerce, and the impacts of information and communication technology on organizations and individuals.

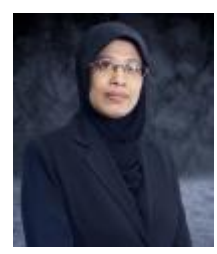

Nursilah Ahmad graduated with BSBA (Economics) degree from University of Denver, USA and obtained her Master and Ph.D in Economics from International Islamic University of Malaysia (IIUM). She is currently a Senior Lecturer and Head of Program, Bachelor of Corporate Administration and Relations (Hons), Faculty of Economics and Muamalat, Universiti Sains Islam Malaysia. Her area of specialization includes international macroeconomics, financial economics and social economics. She has been involved in organizing seminars on issues facing the Malaysian economy since 2002 and has been the editors, paper reviewers and peer reviews for several international conferences and journals. She has written many international and national seminar and conferences papers, journal articles, book reviews, case studies and short articles. Her paper has been published in ISI/Scopus/Citation indexed journals and indexed conference proceedings. 